\title{
[6]
}

\section{A Transformed Occupation}

Although domestic service remains in Zambia today, the occupation has been slowly transformed from what it was in the colonial era. Its persistence masks changes at many levels: in the overall economy, within the servant-keeping population, among servants themselves, of the nature of work done in private households, and of the social relations in the labor process between servant and employer. In this chapter I discuss four specific aspects of this process: the degradation of work; the remaking of difference; the ongoing complaints; and the structuring of consent to the labor regime. Because most servants are men, the discussion refers almost exclusively to the work relationship between menservants and their employers. Much of what I have to say applies to women servants as well, but with a difference, and I take up the questions surrounding the changing gender dynamics in domestic service today in this chapter's last section.

\section{The Degradation of Work}

The work done by servants in private households in the mid-1980s has, according to my survey, been largely reorganized. Gone are the colonial era's task specializations, most certainly the distinct routines carried out by several different servants-the water boy, the bath boy, the wood boy. In many cases the majority of these tasks have been merged into the work of one general servant.

This reorganization shows some similarities to, as well as differences from, the process of deskilling which Henry Braverman identified as occurring during the development of the capitalist labor process in the United 
States. His observations concern the destruction of old crafts which took place as scientific management was introduced and the unity that had characterized the craftperson's work became separated into conception and execution. The labor process thus was reorganized into deskilling and fragmentation, on the one hand, and the creation of an apparatus of conception on the other. Braverman's argument also concerned the expansion of capital into new areas, such as service industries, which transformed domestic work, for example, into an arena of capitalist relations. As capital conquered one sphere after another and as it itself became transformed within the spheres it had already conquered, so were old jobs destroyed and new ones created. ${ }^{1}$

Braverman's observations illuminate but also raise questions about the Zambian case. Its developing capitalism does not approach the stage he describes for the United States. Outside of a tiny sector, chiefly mining, most work continues to be labor- rather than capital-intensive. The availability of a reserve pool of labor has depressed wage levels to the point that it is cheaper to employ people than to use machines. Capital has barely moved into service industries and it has not commercialized private domestic service. Yet postcolonial capitalist developments in Zambia, such as they are, are nevertheless remodeling domestic service. The reorganization has had less to do with technological advances than with changes among the servant-keeping population and in the nature of work done in private households.

The deskilling that Braverman identified in the factory in the United States is taking place in reverse in domestic service in Zambia: onceseparate tasks are being leveled out and merged into the work of one person, today's typical worker, the general servant. The chief householder still remains charged with the conception of the servant's work and its supervision. At the same time, among a tiny fraction of the servant-employing households some of the specialties of the colonial era persist, namely skilled cooks and dexterous houseservants who are men, and another specialty-the female nanny-is assuming unprecedented prominence. While I acknowledge its historical and economic background, the concept of the reorganization of work in domestic service in Zambia in the 1980s as a special process of deskilling is a useful one and I have applied it here to. the ongoing dequalification and degradation of the occupation.

Extrapolating from my survey, a composite description of a general servant in Lusaka would be a man in his late twenties, who arrived from the Eastern Province some seven years ago after dropping out of school; he lives on the premises and is now married and has a couple of children. His

1. Henry Braverman, Labor and Monopoly Capital: The Degradation of Work in the Twentieth Century (New York: Monthly Review Press, 1974). 


\section{Colonial Legacies and Postcolonial Changes}

wife does not do any wage labor. He has held about two places as a servant prior to his present job. As a general servant, he works both inside and outside the house; he does not cook. He works inside the house in the morning, and after his lunch break, in the garden. He sets the dinner table and returns to the kitchen to do the dishes and tidy up after his employers' dinner.

The reorganization of domestic service has been influenced to some extent by the availability in most servant-keeping households of basic amenities such as piped water, electricity, refrigeration, and flush toilets. But it is not the result of the application of labor-saving technology to household management. Even those employers surveyed who had laborsaving devices frequently did not allow servants to use them. Many employers consider servants to be clumsy and fear that they will break things. Many devices were broken down, or not used at all on the well-founded assumption that if they broke, spare parts would be unavailable. The servant's labor-intensive work is monotonous and routinized and offers him few opportunities for learning and expanding his abilities.

Working in this way, the servant develops no new skills and whatever special skills he might have acquired, say, in French cuisine, become inconsequential and are likely to be lost. In that sense, the contemporary servant's work is becoming deskilled. This process is partly a consequence of changes among employers-the entry into the servant-keeping population of more and more Zambians whose household management and cuisine require less elaborate standards than those of the colonial past, and of expatriate households, where the wives spend more of their time working in their own kitchens. The deskilling of domestic work is also influenced, at least at the time I did my research, by shortages of staple foods-flour, yeast, and cooking oil, not to mention spices and condiments-which makes it increasingly difficult for most employers "to keep house like in London." As a result, proportionately fewer skilled cooks than in the past graduate from on-the-job training in private domestic service in Zambia today.

The contemporary servant market is characterized by a paradox: on the one hand, it is glutted with potential servants; on the other, there are positions for cooks, for example, which are difficult to fill. The paradox reflects the coexistence of change and persistence in this occupational domain, epitomized by today's general worker and yesterday's skilled cook. And it is influenced by the mismatch of supply and demand factors in this particular segment of the labor market. There are indeed cooks available, but owing to the pressures of urban living, few of them can afford to wait for a well-paid job to open up in their specialty. Zacchi had to support a wife and dependents out of school and out of work. He told me with regret that he took the job as general servant in a white household, in which the 
madam herself carried out his specialty: cooking. His age mate, Nkuwa, was reluctant to follow Zacchi's example. Unlike Zacchi, he had support and therefore perhaps could afford to be choosy, defending his specialized skills as a cook against the devaluation of his labor. He was not optimistic about his job chances, for as he said with implicit reference to the new expatriates and their different standards of cooking: "the whites eat nshima now." (He was not implying that whites like Zambians eat nshima every day, but that white women do most of the cooking: nshima is supposed to be cooked by the wife in a Zambian household.) When asked whether he would work as a servant in a Zambian household, he smiled broadly, saying: "I can't cook Zambian food." We both laughed, knowing that of course he knew how to prepare Zambian food, but that he did not consider that task to be professional cooking. His point was not that he was unable to cook it but that he did not want to, for in a Zambian household he would be called on for many other duties. It would be below his dignity to be ordered around by another Zambian as a deskilled general servant. Nkuwa's comments implied, as did those of many others in the survey, that servants are critically aware of their failure to defend their specialized skills in domestic service today.

\section{Remaking Difference}

How the relationship between deskilled workers and those who control their labor is organized and structured in practice was not Braverman's interest. His was an abstract theory, not a concern with actual human interaction. In reality, both servants and employers bring intentionality to the workplace. They monitor their behavior in an uneasy relationship of cooperation and conflict that masks the essential ambiguity: its personalized nature. The personalized nature of the work relationship in postcolonial domestic service is not the product of a paternalistic ethos based on reciprocity of obligations between employers and servants. Rather, it is the result of the deteriorating economic situation and the general insecurity of living in society at large. These circumstances force persons with few means to make a living by working for those better situated, who in addition to getting housework done cheaply also get some one to be around the house in a role almost akin to a watchdog.

The colonial period's hierarchical relationship between servant and master was expressed mainly in racial terms, and the unequal relationship between the two interdependent parties accentuated, marked, and recreated a discourse that made the two even more unlike one another. The distinction between servant and employer is today no longer necessarily rationalized in racial terms, but more often in class terms. The antagonisms that such terms veil still revolve around the conception of the servant as 
other and one who is different, that is, less capable or worthy than the employer. This conception turns on the need to uphold the hierarchical distinctions within the private household-between servant and employer-so that work may go on. The conventions that today help recreate these distinctions have much in common with those of the colonial era. They are comprised of informal practices structured by tacit rules that in Giddens's terms institutionalize this domain of activity. ${ }^{2}$

These conventions are expressed in forms of address, in the structuring of everyday interaction, and in the way the two parties conceive of each other when away from work. The servants were in 68 percent of these households addressed by their first names. We noted 20 percent of employers referring to their menservants as houseboys, or boys, when describing the daily routine of the household. Six percent, all Zambians, addressed their married servants in a Bantuized idiom, for example, BaTembo for a man and MaBanda for a woman. Twelve percent of the employers addressed their servants by last name only, and a small fraction, 3 percent, mainly white expatriates, addressed their servants as, for example, Mr. or Mrs. Tembo. Servants were much more formal when addressing employers. Thirty-six percent addressed the heads in the employing household as Bwana and Madam; 28 percent used titles, for example, Sir, or Mr. and Mrs. Brown. Twenty-four percent of the servants in Zambian households addressed their employers in the terms from their respective languages for father and mother, or "father of," "mother of" followed by the name of a child. These are common African forms of address and serve, when used by servants, to acknowledge the status of the employer as a parent to whom respect and obedience is due. When talking of their experiences with different employers, many servants still referred to whites as Wazungu and Asians as Mwenye. ${ }^{3}$ They would typically refer to their Zambian employers as "the owners."

As in any situation of inequality, the needs of the persons in authority determine to a large degree how their inferiors are treated. In the households where I observed daily interaction between servants and employers the servants were obsequious and almost inconspicuous. Most of them worked barefoot, knocked on the door when entering a room to clean it, and did not talk while being around you. Servants who took the initiative to engage you in conversation were considered intrusive. Employers felt imposed on by servants who asked questions about their work, their plans for

2. Anthony Giddens, Central Problems in Social Theory (Berkeley: University of California Press, 1979), pp. 65-73.

3. Wazungu (singular muzungu) is a Bantu term. Its basic meaning is "Europeans," or in general "white people." Mwenye is used for Asians. 
vacation, and so forth. In most of these households, servants did not talk unless spoken to.

Employers' questions to servants are, of course, also intrusive. Because they know that employers do not want to become involved with their personal problems, many servants say nothing in answer, or simply make a downcast gesture. Some employers assume that their position of authority allows them to judge their servants' affairs, and admonish them, for example, to limit their families and to save money for a rainy day. Such patronizing advice is disliked by servants, who have their own plans, and for the most part, they make no comment. When they do speak to the employer, for example, if they need to attend a funeral, take a child to the clinic, need an advance from their wage or to borrow outright, they rarely address the employer directly. They may make their intention to speak known by a slight cough, or they go through the madam, asking her to tell the bwana about the matter at hand. Since most of these matters inconvenience the lives of the employers and the daily routine of the household, the employers are likely to nag before they, grudgingly, permit the servant to attend to them. In expatriate households where servants are not conversant in colloquial English, these encounters are often strained because of communication problems. Such employers generally assume that their servants are less capable of understanding English than in fact they are. To make their opinions clear, they speak slowly and in simplified language, conveying an attitude that infantilizes the servant.

Even in Zambian households where employers sometimes are addressed in the idiom of kinship, inequality is recreated every day in household interaction. Even if they treat you nice, say servants, you are still a servant. If you are out of place, they quickly put you back in your place. Zambians forget, servants say, that you are a fellow black - or, rather, that they are black themselves. Because of their inability or unwillingness to become involved with another black person's economic and social needs, Zambian employers resort to hierarchical practices of interaction with their servants. In their view, although they are of the same race, servants are still other, different from themselves: servants are members of poor families; they have been unfortunate in life; their needs and desires are different; they need less to make a living; in short, their world is inferior. Zambian employers make few efforts to improve their servants' world, for they pay their servants less than do most other employers and in this way help to maintain the class gap.

The social practices that structure conduct in these households help to ensure that servants never become members of them. Such practices are part of the ongoing interaction and they help to reproduce the structure of inequality that defines the relationship between servants and employer. 


\section{Colonial Legacies and Postcolonial Changes}

How do these practices become reproduced? Some newcomers to Zambia, and particularly people without prior experience of employing servants, are initially surprised by the practices that local residents recommend they follow. Some set out paying wages far beyond the going rates, having servants work fewer hours and insisting on doing some of the work themselves, listening to their servants' complaints and attending to their personal problems. Many of these employers insist on not locking up stores and personal things to avoid the feeling of being prisoners in their own homes. They will sit down with the servant and discuss the problems involved in making a living in Lusaka, ask questions about life in Zambia, about differences among the ethnic groups, and encourage servants to approach them freely and ask for help when necessary. Some women involve themselves with their servant's wife, encouraging her, for example, to take adult literacy classes if not trying to teach her and some of the children herself. They demonstrate handicrafts or supply the wife with materials so that she can work with skills she may already have, such as knitting and crocheting; a few of the women I encountered even taught the wife to use a sewing machine. These employers put themselves on a first-name basis with their servants and initially are lax in their household routine, saying "fine" when the servant asks for time off to attend to an unexpected matter. The routine breaks down in many cases, when the new employers realize that they have been taken advantage of. Some servants will exploit newcomers, hoping to get the most out of the situation while it lasts. Things may gradually begin to disappear from the house, and calls for assistance and money borrowing become too frequent. The result is dismissal, if the servant and his household have not already absconded.

Troublesome experieces of this nature typically take place during the first year or two of an expatriate household's residence in Lusaka. Because of the inequality that in the first place brings two persons together as servant and employer, their relationship revolves best around work, not personal friendship. And gradually, the woman householder begins to conform to the unwritten rules that structure interaction in domestic service in Zambia and becomes a madam. She locks up the valuables, communicates little with the servant if she happens to be around when he works, and she avoids involving herself in the personal affairs of the servant and his household. She never really trusts her servant and monitors his activities and changes of mood as he does hers. Then she sees other newcomers go through similar experiences and gradually begin to conform to the unwritten rules, and the cycle repeats itself. She smiles sadly when sharing these experiences with her neighbor, saying: "I told you so. They all learn," thus expanding rather than analyzing the folklore of domestic service.

What servants and their employers say about the other influences how they interact and helps to strengthen the relation of difference that dis- 


\section{A Transformed Occupation}

tances them from each other. ${ }^{4}$ Employers' views of servants can be observed not only in the workplace but in popular magazines, newspaper articles, and classified ads as well. One departing employer, for example, advertised the man who had worked for him in the following terms: "House servant, honest, good with dogs, references available" 5 And, on the other side, reckoning with employers' opinion of women servants, Grace Zulu sought to market herself as follow: "Good house girl available especially to foreigners. I speak good English, I am clean, I know how to wash and iron clothes, do all the work in the house, good to children; and I will be very honest with my job and to you."6

Such advertisements, which use the language of difference, in a way the language in which dogs are spoken of - servant as "pedigreed" with references-provoke no comment in Zambia. ${ }^{7}$ There have been few shifts in the attitudes of the servant-keeping population. Employers buttress their sense of privilege and power by not, in the servants' practical language, treating them as human beings. By accounting for the relationship in terms of difference, employers also free themselves of any responsibility for creating that difference. The servant, for his part, says that he belongs to the common man and so therefore he must work for those who are different and better stationed, the Apamwamba or the Wazungu, ${ }^{8}$ though he does so grudgingly. Nor has the succession from white to black among the servantemploying population altered the language and closed the distance of difference. Although some Zambian employers will say that, after all, servants are also human beings, the discourse of their daily interaction with servants remains the same. Seeing the other as different, servants and employers rationalize their unequal relationship in terms of such difference.

4. Johannes Fabian, Time and the Other: How Anthropology Makes Its Object (New York: Columbia University Press, 1983), pp. 25-35.

5. Times of Zambia, January 1, 1985.

6. Times of Zambia, March 9, 1985.

7. One advertisement did cause uproar, but for other reasons. A Mufulira woman calling herself Elizabeth placed the following ad for two days in succession: "A clean, non smoker middle aged coloured nanny needed to look after one year old baby; a well furnished little cottage and good salary offered." Times of Zambia, January 24 and 25, 1984. She was immediately taken to task in letters to the editor, one of them signed "colourless coloured" who asked: "Who is a coloured? What has colour to do with employment? Are we in Babylon or are we in Northern Rhodesia, or South Africa where colour is the passport? . . I would like to advise this lady to stop behaving like she is in a South African zoo." "Racist Lizzie Caned," Times of Zambia, February 4, 1984, p. 4; and "Employer is Racist," Times of Zambia, April $10,1984$.

8. Apamwamba, a Nyanja term meaning literally "those on the top." They are the persons who live in mumayaadi (i.e., in the low-density areas), and have assimilated the style of life of the colonial wazungu whom they are replacing. In status terms, wazungu could just be another way of saying apamwamba. Professor Mubanga Kashoki helped clarify these terms for me. 


\section{Colonial Legacies and Postcolonial Changes}

\section{Everyday Trials and Tribulations}

The labor process in domestic service turns on the shared need for security: in the form of household comfort and protection of material property for the employer, of economic survival for the servant. A new kind of personalized dependency has been forged between these two unlike partners. Employers describe servants as "a blessing in disguise" and the servants in their turn say " you can never rely on them." In their everyday discourse, servants and employers talk about each other in a language of trouble and tribulations that conveys the contradictory concepts each uses about the other. Following Giddens, I suggest we must reckon with the concepts these actors themselves apply in the course of their ongoing conduct. ${ }^{9}$ For each of them knows, in a practical sense, a great deal about the workings of the institution because they participate in it. What they say about each other does not constitute a description of their relationship; their statements are part of that relationship. As such, their statements about each other affect their ongoing interaction.

Contemporary employers will quite readily join the chorus of oldhands, lamenting that servants are not what they used to be and, to be sure, a good servant is hard to get. They are said to be inefficient, lazy, lacking any sense of foresight; they are not to be relied upon, they never tell the truth; they are irresponsible, they squander their money and disappear without notice. They just never learn and do things their own happy way. "Their way" includes eating different foods and not entertaining as the employers do; they have strange cultural ideas. Their relations to wives, dependents, in-laws, their work habits and notions of time and duty differ. Employers speak almost as if servants were a different species. Expatriate and Zambian employers make these statements, couching the difference between them and the other in terms of lifestyle attributes if not different culture. Employers pass these bits of knowledge on to one another, recreating the notion of servants as distant, and different from themselves.

In the counterdiscourse of servants, the employers are said to talk too much, to be rude, and they walk behind you. Zambian employers are too proud, they don't respect servants, and don't treat them like human beings. Expatriate employers are too odd, they make unreasonable demands; one day they love you, the next they hate you, you just never know. You work hard all day, five days, if not more per week, month after month, on a slave wage, and still they complain that you lack action and initiative. Their ideas about work are inconsistent: they want the beds turned down just so, or else. Their demands change: when they go on leave, they pay

9. Giddens, Central Problems, pp. 245-248. 
you the same wage, though you only have to work in the garden, watch the house, and tidy up before they return. They have weird pantry and storage rules. You know what they have and where it is, yet they hide their valuables and tempt your honesty. The owners, as many servants refer to their Zambian employers, do not share or help out. They are stingy.

Most employers complain about their servants for many reasons and view them as a mixed blessing. A quarter of the employers surveyed said they could do without servants and would rather not have them. "Servants," they say, "are trouble. More trouble than they are worth." Yet they keep hiring them, considering them "a necessary evil." They have a hard time defining what it is they want in a servant beyond vague intangibles such as a good personality, or their being good with children. Because servants are hired not so much for their skills as for their personality, employers have difficulty ensuring their full cooperation, since servants do not know what to expect. Some take on servants because both spouses work, and because they have children. Others because of the weather: the tropical climate and the red dust that creeps in everywhere, the frequent need to change clothes, and the corollary of piled-up laundry and constant ironing to get rid of putsi flies-in short, they say there is too much housework. Others again have been used to servants for so long that although they do not really like them, they still find them useful to have around. Many rationalize their need for creature comfort by saying that at least they create jobs for persons who otherwise would not be employed. Paradoxically, most employers agree that they never really trust their servants, yet they employ them because of their need for security.

Most servants complain about bullying and mistreatment, lack of consideration, and, not least, low wages. They would like to have different jobs, and 75 percent of the servants surveyed said they hoped their children would not end up in domestic service. Yet they go on working in a job for which they say they are paid substandard wages because of lack of choice in the employment market. They need their employers in order to survive.

Post-colonial employers and servants in Zambia thus need one another in a very special sense that makes both sides vulnerable. The frictions that troubled domestic service during the colonial period continue to characterize it, but the concerns of the two parties have become accentuated because of the runaway economy. Security-conscious private householders, who live in a city where petty theft, break-ins, and armed robberies serve as regular means of material redistribution, need servants on the premises to guard their material possessions. This creates a dilemma. Since employers never really trust their servants, they need to watch them as well. The atmosphere in the household is openly characterized by distrust: employers lock up their valuables; more than one-third surveyed said they re- 


\section{Colonial Legacies and Postcolonial Changes}

tained their servants' National Registration Cards (which is illegal) in the belief that it would deter a servant from absconding or help in tracing one who had done so. You never know, they claim, what kind of company the servant keeps; he or she may be in cahoots with thieves. There is no end to the stories, most of which are true, of long-trusted servants who suddenly stole from their employers. Thus no matter how many complaints you have about the servants' work efficiency, you maintain a modicum of good relations to prevent them from turning against you.

Servants on the other hand, although most receive substandard wages, continue to work in a manner that does not upset the employer too much. They depend on intermittent handouts to supplement their meager pay. Those who work for expatriate employers cherish hopes of receiving a gratuity when the employer leaves the country. Those who work in Zambian households today try to improve their conditions by looking for betterpaying jobs. All servants hope that their present employers will help them find better situations in food service, for example, or as janitors at the employer's place of work. Meanwhile, they set their own limits as to what is tolerable in terms of workload and supervision. Because the market is shrinking, unless the work is plainly intolerable, many servants stay put, and the problems between them and their employers continue.

\section{Structuring Consent}

Unlike during the colonial period, when coercive rules and regulations governed employment according to a hierarchical regime, today consent to the labor process in domestic service is based on shared need for security. The conduct of servant and employer continues to be framed by an unequal interdependence fraught with ambiguities. These arise from the fact that the interpersonal nature of the relationship masks its fundamental class basis. Social practices, spoken of in a vocabulary centered on problems and trouble, help to maintain and reproduce this class relationship. In some of the existing work on servants such behavior has been analyzed as examples of submission to a personalized regime, in others as rituals of deference. ${ }^{10}$ But although their relationship to their employers differs from that of other workers because of the personalized nature of the labor process in domestic service, servants are wage laborers and part of the working class, at least in objective terms. I suggest that studies of the relation between workers and employers in other occupational domains may throw light also on domestic service.

To make the class aspect of the worker-employer relation central to a

10. Judith Rollins, Between Women: Domestics and Their Employers (Philadelphia: Temple University Press, 1985), pp. 155-173. 


\section{A Transformed Occupation}

discussion of domestic service requires a refocusing of the questions. Rather than asking why servants defer to the hierarchical interpersonal regime in domestic service, why their work performance is poor, and why they are untrustworthy, we might ask why at all they work as hard as they do under a labor regime that compensates them so poorly.

Their employers attribute problems with servants to extraneous factors such as servants' lack of education, their family ties and complications, cultural conventions, and so forth, which servants bring with them into the workplace. In his work concerning a Chicago machine shop, Michael Burawoy demonstrated how the organization of work relations on the shop floor was dominated by "making out"- a sort of game workers played with the rules that governed the tasks assigned by the management. ${ }^{11}$ Such games are not frivolous play, but practices designed to do battle with the conditions of work. Through them workers sought to manipulate the tasks within the context of the established rules. Workers, in other words, do not confront their imposed conditions as passive objects; they actively seek to affect them. But by manipulating the rules, workers also lessen the potential for class conflicts to arise between themselves and management, for both parties must cooperate to some extent with one another so that both can continue with their different job tasks. The games workers play generate consent to the rules and allow the system to go on without challenge. ${ }^{12}$

Why do domestic servants in Zambia consent to work in a hierarchically structured employment situation in return for low wages? To answer this question I follow Burawoy, suggesting an explanation that uses factors characteristic of this particular work locus, rather than features that employers allege are peculiar to the servants' personal lives. Among these factors are low pay, poor work conditions, and short-term employment prospects.

In terms of the purchasing power of their wages, servants are worse off today than during the colonial era. Other segments of the working class have also been affected by runaway inflation, but the wage gap between servants and these other groups has widened increasingly. While servants during the colonial period got rations as part of their employment package, few do so today; in fact, the ration system was legally abolished at independence. Although some employers hand out food and used clothing occasionally, such handouts rarely form a regular contribution which the servant can count on in his or her own budget. Domestic servants are not organized and their conditions of work not regulated by any union agreements. The regulations of the 1965 Employment Act are unknown or ig-

11. Michael Burawoy, Manufacturing Consent: Changes in the Labour Process under Capitalism (Chicago: University of Chicago Press, 1979).

12. Ibid., pp. 66-93. 


\section{Colonial Legacies and Postcolonial Changes}

nored, and the ZNPF servant registration scheme ensuring them pensions is not widely complied with. These omissions facilitate a despotic organization of work within the household and take us to the next factor: poor work conditions.

The majority of today's servants are general servants who work both inside and outside the house. In such a generalized work regime, a servant's previous skills, as I suggested earlier for example in cooking, become redundant when the new expatriate madam insists she likes to cook and asks her manservant to scrub the toilet bowl, wash her undies and cut the lawn. Some servants, like Zacchi, openly regretted not being allowed to cook for his white employers. But not all general servants who had cooking skills divulged it to their new employers. Keeping such knowledge to themselves they resisted any additional claims employers might place on their already overtaxed labor time. The working hours are generally long, although there may be a lunch break and the employer says there is not much work to do in and around the house, and the servant spends too much time doing it. But if they weren't doing it, there would be something else, for "work never stops," and although the servant lives in quarters on the premises, time is rarely at his own disposition; he simply is available, or made to be so at the employer's discretion.

The work conditions and the daily routine have to be agreeable first and foremost to the employer, who sets the rules and dislikes being inconvenienced by a servant's wish to change his weekly day off from Saturday to Sunday so that he can attend church. The servant is subject to arbitrary and personalized domination-despotic, benevolent, or otherwise. If the servant's ways confront the employer's, he is said to be cheeky, insolent, rude, or irresponsible: "they never learn." What servants do learn is to consent to this regime. To carry out orders and do whatever meaningless work they are asked to do. They know that if they cannot tolerate the regime, there are many others to replace them. But they do not consent as passive automatons to orders handed down from above. They work at their own ease, and one of the games of "making out" in domestic service is to keep up the appearance of always working so that one is not pressed with new demands. By saying that servants are slow and lazy, the employers themselves expect a low work input and use it as a standard for evaluating their servants' work and to structure the future allocation of tasks within the household. While the servant fears losing his job if he does not consent, the employer never really trusts him and accommodates to some extent to the slow routine so as not to upset him unduly and antagonize him. Working alongside each other in this process of mutual monitoring, the inequality inherent in the situation is never confronted, and the relationship between the two parties, mediated by a precarious and skewed interpersonal dependence, is continually reproduced. 
Servants know that their tenure is likely to be short, for today's expatriate employers come and go, and middle- and upper-income Zambians are transferred across the country frequently. In addition, if the job does not work out, prospective employers can hire from a market glutted with potential replacements. Because they are so easily replaceable, some servants are reluctant to take their annual leave even if it is offered to them. They fear the employer might hire a temporary replacement to whom he takes a better liking. To prevent this, sometimes a servant leaves his wife, or a young adult son or relative, behind to do the work in the house when he himself goes elsewhere for a break. In fact, some employers insisted on the servant's wife being left behind in order not to be inconvenienced when the manservant took his vacation time. "They never go anywhere together, anyway," some employers say. Some servants accommodated within limits they set to the employers' whims and tried to make the best out of it while it lasted, hoping to receive help and assistance in return for proper consent and that a new job might materialize once the employer leaves. In new jobs, the work routine with similar expectations on either part is reproduced again.

Those servants who work in the lowest paid jobs with the worst work regimes contest it by shopping around for better jobs. They are the ones who have come today and are gone tomorrow, and who leave without giving notice. Given their low wages, they work no longer or no more than they consider fits their remuneration, and some also help themselves to what they view as their due from the employers' household.

What servants and their employers grapple with in their troubled interaction is fundamentally an economic issue: the creation of survival and security in which they each have a different stake. Some extent of cooperation is necessary for it to be achieved, which requires consent and accommodation on both their parts. To explain the reasons for their different roles in the process, employers call up rural-urban, cultural, and ethnic differences. But what employers consider to be inherent characteristics of servants themselves, features they bring with them into the workplace "because they are different," arise at the locus of work itself and independently of the particular individuals who happen to fill the positions as servants. What employers and servants say about each other therefore reflects the practical knowledge they apply in the course of their conduct at the locus of work and helps reproduce that conduct. So, servants work slowly because, as explained above, work never stops. Knowing that his or her servant does no more than asked, and slowly at that, the employer repeats orders and says servants are lazy, for they never take any initiative. In the servant's language, the repetition of orders amounts to talking too much or too loudly; and checking up on his work by walking behind him amounts to supervising. The servant does not take any initiative for if he 


\section{Colonial Legacies and Postcolonial Changes}

did, he would not get any better pay, and if he speeded up his work, he would be assigned another task. And if he argues about ways of doing things, he is said to be rude and cheeky. So he says nothing and is called insolent.

Yet the employer tries not to go too far. For with servants, you just never know; you cannot really trust them. Therefore, you should not upset them too much for there could be repercussions, such as a burglary by the servant you just fired. So, some extent of pilfering is tolerated, for after all you do not trust your servant. And if, after you have asked him five times to deal with some plants in the garden in a certain way and he still does not do so, you stop; you do not want to nag too much. After all, this servant has not to your knowledge been involved in anything against you, he has been with you for some time, knows your whims, and you dread the thought of getting used to a new servant who you may not like or may trust even less than this one. On they go, the servant intentionally being slow and, as expected by his employer, in need of constant supervision; the employer purposefully checking up and, as expected by the servant, never really trusting.

In this way the participants in domestic service bring their practical understanding of the wider surroundings and the circumstances of their interaction to bear on their conduct in a process of mutual monitoring that creates consent to, and reproduces, their unequal relationship. Intentionality, as shown in these examples, is a routine feature of the conduct of servants and employers. Their efforts to anticipate each other's moods so as not to upset the precarious balance required in their employment relationship mutes the potential for conflict between them and the work goes on. The tacit rules they set for themselves in their mutual conduct stem from their knowledge of how to go about doing things, given the circumstances of domestic service and the nature of the broader economic surroundings. Conceptualized as structuring properties, such social practices are not barriers to action but rather are involved in its production. This is Giddens's notion of the duality of structure, ${ }^{13}$ according to which actors draw on the knowledge they have of one another's conduct in the production of their interaction in domestic service. In the process, their conduct also reconstitutes the institution they interact in without changing the fundamental inequality that underpins it.

\section{The Woman Question in Postcolonial Domestic Service}

The typical domestic worker today is the male general servant and for this reason my discussion about the problems between servants and their

13. Giddens, Central Problems, p. 71 . 
employers in the daily performance of domestic work centered on men. In households employing women servants, the same process is played out but with an added dimension of sexual tension. Women are now entering domestic service in larger numbers than ever before, and the causes and consequences of their entry need to be explored.

What did BaNkuwa have in mind when he said: "If I had known this would become a woman's job, I would have sought work as a driver?" His reference, as I understood him, was to the general deskilling of postcolonial domestic service, rather than to the replacement of men by women in the occupation. It is the fact of having to cook for Zambian employers that makes domestic service a woman's job in the view of long-time menservants. In traditional Zambian households, the wife cooked for her husband. Some contemporary Zambian wives continue to do so, while their servant is allotted the job of cooking for the children-yet many more of them assign the task to their menservants. BaNkuwa, who was a skilled cook and proud of it, did not want to work in a Zambian household; he did not want to do "woman's work.

Women in Zambia today are not replacing men domestic servants for they work primarily as nannies. Boserup's often quoted thesis about the link between economic development and the gender division in domestic service needs to be reevaluated, at least for this case. With economic development, Boserup suggested, the domestic service sector would grow and in the process tend to become more feminine. ${ }^{14}$ Two observations certainly warrant attention in the Zambian case.

First, the kind of economic development envisioned by Boserup was predicated on a theory of modernization which has not held up too well when applied to the economic experiences of many developing countries. Zambia's economic growth has not been accompanied by an expansion in urban employment commensurate with the increase of the labor force. After the unsuccessful campaign for African womanpower in the postwar years, men did not leave domestic service for there was little work for them in other occupations. This pattern has persisted after independence, and as we have seen, employment statistics show dramatically that Zambian women continue to have difficulties in finding waged work.

The second factor concerns the construction of gender, the diverse ways it enters into economic and social relations in different societies and the way it changes, or persists, over time. These processes need to be examined in studies of economic change and their different effects on women and men. In Boserup's scheme, broad contrasts were noted. in most of Latin America servants are female and in much of Africa they are male. ${ }^{15}$

14. Ester Boserup, Woman's Role in Economic Development (New York: St. Martin's Press, 1970), p. 104.

15. Ibid. 


\section{Colonial Legacies and Postcolonial Changes}

But her reference to the important role African women played in cultivation hardly explains the persistence of men in domestic service. While women's work in cultivation certainly is important, its significance has varied in different countries over time owing to colonial and postcolonial changes in agricultural policy and markets, as well as to natural disasters. Indeed, the entire question of whether or not, when, and where men dominated in this particular occupational sector in Africa, is difficult to answer at the present time because of the anecdotal nature of our knowledge. In the Zambian case, the economic development process has followed a different pattern from that anticipated by Boserup. This process and local cultural practices have helped facilitate the construction of the gender division of labor in domestic service in such a way that women are considered less suitable for such work than men.

Domestic service in Zambia is thus not at the present time undergoing a gender transition from male to female. Men remain in service, and women's entry is simply extending an already established occupational domain. Most of the women who enter service are not taking over men's jobs, but do tasks associated with child care. We might speak rather of an unfolding recomposition of the gender division of labor in domestic service in Zambia. ${ }^{16}$

This process of gender recomposition is influenced by several interrelated factors, of which I briefly discuss three: the ongoing change in demographics of the servant-keeping population to Zambian background and its corollary, the decline in the expatriate population; the general deterioration and stagnation in the urban economy, which is expanding the labor supply to include women as potential servants; and the persistence of a variant of colonial gender ideology which construes the gender of women servants in terms of sexuality and continues to restrict their employment prospects.

As a result of the indigenization of the economy in the wake of independence, black Zambians today numerically dominate the servant-keeping population. There has been a substantial drop in the number of expatriates employed, from 32,100 (12 percent of the workforce) in 1964 to 11,900 (less than 1 percent) in 1985. One expatriate category, whites, comprised almost

16. I prefer this to the theory of labor market segmentation which Evelyn Nakano Glenn uses in her study of Japanese American women servants in the United States: Issei, Nisei, War Bride: Three Generations of Japanese American Women in Domestic Service (Philadelphia: Temple University Press, 1986), pp. 12-14. Factors such as race and sex are here held to direct women into the secondary labor market characterized by precarious security and low rewards. A "ghetto effect" results, for segmentation is reproduced by patterns of institutionalized discrimination. Such an explanation is not satisfactory in the Zambian case. It does not account for the inequality between men's and women's positions within this particular sector, and it fails to examine the way in which overall gender stratification feeds into this particular sector of the labor market without displacing men. 


\section{A Transformed Occupation}

10 percent of the urban population during the late colonial period, and their numbers have fallen considerably since independence. By 1969 they accounted for only about 4 percent in Lusaka, Kitwe, and Ndola, and in 1980 under 2 percent. ${ }^{17}$ Because of the differences in childbearing and childrearing patterns between Zambian women today and the white women of the colonial era, a special niche has opened up within domestic service for women to work as paid nannies for their wealthier countrywomen. This is not to say that African women never worked as nannies during the colonial period, but they were the exception, not the rule. Colonial white women had fewer children than do today's Zambian mothers. Because many children were sent to schools in Southern Rhodesia, South Africa, or Great Britain, their mothers had fewer worries about their dayto-day supervision than have postcolonial Zambian women. Zambian women householders thus need nannies to attend to their children while they themselves go out to work. And many Zambian women who do not work away from home want relief from child care if they can afford it. Creches and nursery schools do not have the facilities to accommodate the growing number of preschool children, and even if places in such institutions were available, they would be too expensive for most Zambian mothers. Nannies are cheaper.

A small proportion of Britons and white South Africans have remained in Zambia since independence, but the majority of today's expatriates originate from other countries throughout the world. Few have ever lived in racially structured colonial settings. They rarely accept the received wisdom passed down by the previous colonial generation about the problems involved in employing African women as servants. Expatriates who accept contracts in Zambia are usually older householders with teenage children who often are attending boarding schools in their home countries; thus their needs for domestic help are different from those of most Zambian householders. Those expatriates who do have small children sometimes employ nannies, and some let women servants do the general work inside the house, occasionally including the cooking. Those who employ nannies have the same turnover problems as those experienced by Zambian women householders. Asian householders continue to employ African women as servants rarely if ever.

Zambian women seek jobs in domestic service as a last resort, particularly in situations of family crisis, and because they have few alternatives. If they can avoid it, domestic service is not a lifetime choice. The hours are long, the remuneration poor, and further, service conflicts with the demands of married life. Although those demands place limits on women in

17. The Economist Intelligence Unit, Country Profile: Zambia, 1987-1988 (London, October 1987), p. 14; Anthony O'Connor, The African City (London: Hutchinson, 1983), pp. 103104. 


\section{Colonial Legacies and Postcolonial Changes}

ways that vary by class, by rural versus urban residence, and by age, most women are, within those limits, fairly autonomous in the everyday management of their own domestic work. That autonomy is lost, however, in paid domestic service.

My survey shows that the women who worked in domestic service fell into two broad categories. They were young school dropouts from rural areas who had come to town, sometimes leaving a child behind with relatives, and worked in very low-paid jobs, primarily as nannies, sometimes live-in, in Zambian households. Or they were middle-aged, close to or beyond the end of their childbearing years, long-term urban residents, often single heads of households because of divorce or death of a spouse. They worked in better-paid jobs as indoor household servants, especially in expatriate households, and lived-out with children and dependents.

Women's work in domestic service thus differs from men's in many respects. Women's chief activity focuses on child care and tasks associated with it, their jobs have the highest turnover rates, and they earn, with a few exceptions, by far the lowest wages (since it is assumed that they "last" a shorter time than men owing to their personal problems). Proportionately fewer women than menservants live in, and women's employers frequently do not pay the statutory housing allowance to low-income workers on the assumption that their women servants are wives or dependent members of households and therefore have shelter elsewhere.

The "nanny problems" of Zambian women begin with the birth of their first child. At this point in their household's development cycle they typically fetch, or are brought, a distant female relative from the countryside, often a teenage girl who has dropped out of school or whose parents are unable to pay for her education. She is fed and clothed and shares sleeping space with other members of the household, yet is at their beck and call. She rarely lasts from the birth of one baby to the next, which is to say at most two to three years. Problems of discipline quickly arise, for the young girls dislike being ordered around and want freedom to explore the city as well. If they stay for three years, they are generally returned at the end of that time or collected by their parents, the rationale being that to "detain" them longer might reduce their marriage chances. The longer they stay in town, the more likely they are to be "spoiled," that is, made pregnant, which reduces the size of the bridewealth their fathers or guardians may claim. Because of the ties of distant kinship, Zambian women householders can neither command the complete obedience nor control the full labor of these young girls. After their trials with usually several young country relatives, they turn next to paid women servants, who cause even greater problems. Many householders prefer rural women who are new to town for they are assumed to be less venturesome in matters of sex. Their period of service is deliberately kept short, to avoid the possibility of familiarity 
developing and the likelihood of intimate encounters with the male householder.

Once their last-born child has entered school or the older children are considered responsible enough to watch their younger siblings, Zambian women hire men servants. They recount their experiences of employing women in a troubled voice: women servants are insolent and cheeky; they only do the work they feel like doing; in addition, they steal; they go through your underwear and toiletries. But worst of all, before you know it they move into the bedroom and take over the house. As part of the collective consciousness of Zambian women who employ their countrywomen, stories of women servants usurping the place of the wife abound and are featured in popular newspaper columns and women's magazines. ${ }^{18}$ The sexuality issue thus continues to shape the gender construction of women servants in postcolonial Zambia; the race of those who frame it has changed, but for women who must work in the occupation, the effect remains the same.

\section{The Postcolonial Sexuality Argument}

In the view of Zambian women householders, the "woman problem" in domestic service arises from the loose morals of their female domestics, who are always on the lookout for a man either to marry or to "keep them nicely." Being kept nicely in Zambia means receiving shelter, food, and clothing. This oversexed image Zambian women householders attribute to their female domestics is not a product of the tasks these women do in service or of their biology. Rather, as Michelle Rosaldo has observed, such a construction results from the meanings that women's activities acquire through actual social interaction. ${ }^{19}$ Poor women's attempts to secure their own and their dependents' livelihood through support from a spouse or a consort clash with middle- and upper-income Zambian women's needs for child care. For the woman who takes a job as nanny seeks to quit as soon as she has some economic means in her own household.

To account for this tension, we must explore the power dynamics of gender within the household, the structuration, in Giddens's term, of relations between the sexes ${ }^{20}$ within it and the way these dynamics enter into, and affect, women's and men's places in the wider social context. Paid domestic work does not in the Zambian view constitute proper women's

18. For example, "Georgette, My Wife," Woman's Exclusive 5 (Lusaka; 1983): 7, 9, and 17, and popular Zambian columnist Kapelwa Musonda, "House Servant Outwits Owner," Times of Zambia, January 8, 1985, p. 4.

19. Michelle Z. Rosaldo, "The Use and Abuse of Anthropology: Reflections on Feminism and Cross-Cultural Understanding," Signs 5 (1980): 399-400.

20. Giddens, Central Problems, p. 115. 
work, for it is considered not "natural" for a woman with small children to leave her own household to attend to someone else's. While on the one hand they seek economic support from men, they wish to be able to act independently of them on the other. Most urban studies in Zambia have shown that male/female relations are filled with anxiety and that relationships are very unstable. ${ }^{21}$ Regardless of the different ethnic backgrounds of the towns' populations, the gender dynamics within households turn on an age- and male-based hierarchy of authority. Across class, male-female relations are largely asymmetric, and although of course there are exceptions this observation is widespread enough to establish that, generally, husbands assume domestic authority. Marital relations are often fraught with tensions, in part due to the persistence of customary marriage practices permitting polygyny, and, perhaps influenced by this, to the existence of a double standard that condones extramarital sex for men. Women will go to great expense to buy love medicines to attract a man's love and assure his financial support. ${ }^{22}$ Yet they also know that they cannot rely on men. Unlike in many West African countries, cultural norms in Zambia do not oblige men to distribute part of their income to wives for household purposes. The money allocation system between husband and wife depends entirely on his goodwill. Even if Zambian men have ample economic means, only a portion of their disposable income reaches their own households.

While women seek to get and maintain support from men, they also are concerned to ensure the day-to-day survival of their children and to make economic gains in their own right. As they grow older, and their children leave the household, Zambian women become less concerned with the pursuit of men's attentions and concentrate their efforts on making an income they control themselves. This shift helps account for women's dual participation pattern in domestic service, which I identified earlier: the young women who come and go in the low paid jobs are struggling to establish their own domestic menages, whereas the middle-aged and older women in longer-term employment and at better wages often are single heads of their own households after divorce or death of their husbands. Men may come and go in their lives, for they do not mind being kept nicely, yet they do not want men around on a permanent basis. Extrapolating from their own and their adult daughters' experience, they say that

21. Bonnie B. Keller, "Marriage and Medicine: Women's Search for Love and Luck," African Social Research 26 (1978): 489-505, and "Marriage by Elopement," African Social Research 27 (1979): 565-585; and Ilsa M. G. Schuster, New Women of Lusaka (Palo Alto, Calif.: Mayfield Publishing Company, 1979).

22. Keller, "Marriage and Medicine"; Benetta Jules-Rosette, Symbols of Change: Urban Transition in a Zambian Community (Norwood, N.J.: Ablex Publishing Corporation, 1981), pp. 129-163. 


\section{A Transformed Occupation}

men cannot be relied on: "as soon as they see someone they like, men drop their wives, or they take another one on the side."

These tensions exist also in Zambian servant-employing households. Husbands may feel freer to pursue sex and change partners than women because under matriliny offspring are considered women's children who in case of divorce would belong to her group. Zambian women householders seek to identify themselves sexually as their husband's women at the same time as they are aware that husbands have other choices. They will make statements to that effect, if not about their own husbands, then about a neighbor's. To prevent extramarital relations from happening within their own household, they prefer to employ menservants. Although a couple of cases were brought to my attention in which a manservant was alleged to have molested the employer's young adult daughter, male sexuality has not entered popular folklore to affect the way the male servant's role was constructed in gender terms. The class gap between him and the employer is generally held to account for the difference between them, the manservant being merely seen as a poor, unskilled worker, unfortunate perhaps because of lack of education or family circumstances, leading a different life and having needs and problems quite unlike those of his employer.

If menservants were spoken of in a language of difference, women servants were even more so. As I noted in the preceding section, Zambian women who employ their countrywomen as servants speak of them in invidious terms. Their distrust of their women domestics expresses itself in a discourse of sexuality which accentuates and dramatizes their women servants' struggle for a livelihood. It also distances female employers from their less fortunate countrywomen who may have neither husbands nor homes of their own. These expressions veil a difference of lifestyle, a class gap, which they make sure not to bridge. Yet they do have one thing in common, although for different reasons: their interest in men. The servant wants a person to support her and her children so that she no longer needs to do someone else's domestic work, and her female employer wants a husband, certainly to support her children and to legitimate her economic and social pursuits as a mature social person, properly married. Their shared interest creates sexual hostility which further distances them from each other. ${ }^{23}$

The oversexed gender image Zambian women householders attribute to their women servants is a product of the way they interpret their women servants' activities and interaction and brings about a special body politic within their own households. Since they believe that their women servants

23. Laurel Bossen describes a Latin American variation on this theme involving different cultural factors from those prevalent in the Zambian case: "Wives and Servants: Women of Middle-Class Households, Guatemala City," in Urban Life: Readings in Urban Anthropology, ed. G. Gmelch and W. Zenner (New York: St. Martin's Press, 1980), pp. 190-200. 
may indulge in sexual affairs with their husbands, they restrict them by rules that reduce their opportunity for contact with the male household head. The chief rules revealed in my survey concerned bedrooms and the preparation of food. Both domains are sexually charged: in the rural societies described in the ethnographic literature of this region these domains were surrounded by special precautions: spatial segregation by age of sleeping quarters, restrictions on women's cooking for men during menstruation, and abstinence from intercourse before important celebrations and events. ${ }^{24}$ Neither men nor women servants were allowed to enter bedrooms in most of the Zambian households in the survey, and in several of them women servants were asked not to cook for the male head of household. In these cases the Zambian women householders feared that their female servants would mix love potions into the husband's food in order to attract his sexual attentions. For the most part, those servants who did cook were men, and even in some of these cases the wife took personal charge of preparing her husband's main meals. As a result of their own effort to encourage their husbands' attentions, many of these women bear children at regular intervals. And because of their need for child care, they tolerate the presence of their Zambian nannies. As these nannies come and go, their employer's problems with them are reenacted and the structured inequality between the two main protagonists recreated anew.

Although the coming of independence broke the hegemonic fusion of gender ideology and employment practice which helped keep African women out of domestic service during the late colonial period, women's sexuality in the view of some Zambians today continues to exercise a constraint on their employability. The parties who advocate this view have changed, for colonial white women's fear of African women's sexuality is today expressed by Zambian women who employ their countrywomen as servants. The concerns of both these categories of women centered on their husbands' opportunity for extramarital involvement with, in the colonial case, a woman of the other race, and in the postcolonial case, one of the other class. The gender ideologies that built on these fears reflect the prevailing socioeconomic orders of their time in both their patriarchal and class dimensions. The pronounced accent on women's sexuality in the postcolonial gender ideology is linked in complex ways to the hierarchical gender dynamics within households and the growing class gap that the economic downslide since the early 1970s has been fostering in Zambia.

24. For examples of some of these practices, see Audrey A. Richards, Chisungu: A Girl's Initiation Ceremony among the Bemba of Zambia (London: Faber and Faber, 1951), Victor W. Turner, The Drums of Affliction: A Study of Religious Processes among the Ndembu of Zambia (Oxford: Clarendon, 1968), and C. M. N. White, "Elements in Luvale Beliefs and Rituals," Rhodes-Livingstone Papers, no. 32 (1961). 